\title{
In Pandemic Times: An Analysis from the Perspective of Public and Private Employees in the Home Office
}

\author{
Maria Clarice Alves da Costa * \\ Federal University of Rondônia - UNIR/ Brazil - Center for Applied Social Sciences- NUCSA, Campus José \\ Ribeiro Filho, BR 364, KM 9,5. s/n. CEP: 76.815-800, Porto Velho, Rondônia - Brazil \\ E-mail: mariaclaricecosta@hotmail.com \\ Sandra da Cruz Garcia do Espírito Santo Aguiar \\ Federal University of Rondônia - UNIR/ Brazil - Center for Applied Social Sciences- NUCSA, Campus José \\ Ribeiro Filho, BR 364, KM 9,5. s/n. CEP: 76.815-800, Porto Velho, Rondônia - Brazil \\ Email: sandra@unir.br; sandrinhamagal@hotmail.com \\ Tomás Daniel Menéndez Rodríguez \\ Federal University of Rondônia - UNIR/ Brazil - Center for Applied Social Sciences- NUCSA,Campus José \\ Ribeiro Filho, BR 364, KM 9,5. s/n. CEP: 76.815-800, \\ Porto Velho, Rondônia-Brazil \\ Email: tomas@unir.br
}

\begin{abstract}
The Covid-19 pandemic was like a tsunami for companies. Before, an environment marked by the electronic punch clock, with limited hours, and then, public and private employees had to stay in their homes and deliver the same or more productivity to their companies. Due to this new global reality, this study was proposed with the objective of understanding how public and private employees perceive work in the home office during the pandemic period. For this understanding, the study used qualitative methodological procedures with exploratory characteristics. With appropriate consent, questionnaires were answered through the WhatsApp, which were answered through audio and subsequently validated by company participants, in a total of 28 participants, fourteen from the public company and fourteen from the private company, of both genders. The questionnaire consisted of a structured script with 18 questions, and was divided into two stages. In the first, there are questions about personal data and the second, questions about digital settlement. As a result, there was disbelief that the disease could reach Brazil; the level of anxiety by most employees of public and private companies; the difficulty of dealing with the new work environment, the family and the new discovery that one can work at home and reaching the goals. The understanding of working in a home office in a time of pandemic is that a new scenario will light up in companies, through demand from employees, to continue exercising their activities in a family environment, which will require new concepts of people management.
\end{abstract}

Keywords: Pandemic. Home office. Public and private employees.

DOI: $10.7176 /$ RHSS/11-10-01

Publication date:May $31^{\text {st }} 2021$

\section{Introduction}

The third decade of the 21 st century was accompanied by an unexpected fact at a global level, the spread of Coronavirus (Corona Virus Disease), bringing Covid-19 (World Health Organization [WHO], 2020). Although the disease started at an extreme point outside Brazil, in Asia, it did not take long to land in the country. At the beginning of the expansion of the virus, without studying the severity of the disease, it was considered a flu, until then an epidemic was thought to be limited to the country of origin of the disease. However, it was a pandemic, declared by the World Health Organization - WHO, on March 11, 2020.

With the advance and seriousness that the case should be conducted, actions at managerial levels should be taken in the public and private sectors across the country. One of the measures established in some companies was the adhesion of some sectors to the home office, in activities that would have no detriment to its development. Therefore, there was a need to adapt individuals to the work environment, with a concern for the family environment, in terms of customs and space for the development of the activity, with the imperative of formulating routines that balance the reality of work in domestic environment (RafalskI and De Andrade, 2015).

The work from home office, according to a study by Hill, Ferris and Märtinson (2003), concludes that the understanding of the positive responses on the balance between work in relation to life and greater personal perception related to the family; as for the motivational factor, it was positive due to the fact that the employee had the possibility of flexibility of the place to carry out the activities and how to carry them out; however, in terms of career advancement, there were objections to being physically distant from the work environment, which could be negative when choosing to progress. 
Thus, the objective was to understand how public and private employees perceive work in the home office during the pandemic period. The analyzes were carried out through interviews with twenty-eight participants among employees from the private and public spheres, in order to answer the following problem: how do public and private employees perceive work in the home office in time of the Covid-19 pandemic?

To reach the objective, the home office concept, understood by Kurkland and Bailey (1999), was used as home telework, to which employees regularly work at home. At the organization level, there is an opportunity for a better work environment and productivity; employees have more flexible hours; and, finally, according to this study, home office employees have a lower disease rate, higher job satisfaction and higher performance in activities.

The analyzes contained in this article are justified by the contextual relevance of the consequences caused by the pandemic in the scope of public and private companies, but also by the use of a theoretical approach distinct from theological or sociological bases, associated with the behavioral and social reflexes of employees in a pandemic period. Thus, it is intended to advance knowledge about the changes imposed on employees, contributing in an analytical and empirical way.

\section{Theoretical foundation}

The theoretical basis of this article is made up of definitions and discussions on digital functional agreement and the Covid-19 pandemic. In this way, it is understood that the fundamental conceptions on the theme are allowed for guidance as the analyzes that follow in this work.

\subsection{Digital functional settlement}

The access to information brought significant changes to contemporary society, which made it possible for employees to access work activities in the space and time they wish, through different communication devices; however, the perceptions reveal negative consequences in a society in which the worker's entire time is working time (Oliveira, 2017). According to the author, the negative impacts include social relationships, difficulties in family relationships, friendship and affective relationships, health problems such as Repetitive Strain Injury and Work-Related Musculoskeletal Disorders (RSI / WMSD), mental, stress and anxiety, and the subjective aspects and emotional health are points that must be understood due to the relationship between work, digital technology and the ways in which it will be controlled and the access of users.

The expression "frontier work" used by Nippert-Eng (1996) in his study, proposes as strategies, principles and practices to create, maintain and modify cultural categories, a continuous, practical and visible process in which individuals negotiate borders. In this case, according to the author, "frontier work" allows the existence of categories and classification systems, which have a degree of significance and vary over time; that allows culture and society to also change; the integration in the process of classifying, assigning and defending the inclusion/exclusion of categorical contents in specific mental and physical spaces and times, reveals the orientation that lives are collective mental structures.

The "frontier work" is, therefore, the process in which the "I" is created and maintained in different "territories" adopting two configurations: work of positioning the frontier and work of transcendence (or transition) of the frontier, being that the placement work establishes a line between kingdoms and 'selves', while the transition work shapes the line, which allows movement over it; if there is any obstacle between home and work, those involved in domestic work are concerned only with common dimensions of the border; and in proportion, it distinguishes and mixes categories of objects and me, such actions help to reinforce and reproduce cognitive relations between home and work; in this case, managing strategies takes place in the mental settings of home and work, not only in the culture itself, but in everyday personal life, concludes the author (NippertEng., 1996).

In turn, Kurkland and Bailey (1999), conceptualized home office as the work that employees regularly perform at home. The authors propose that at the organization level there is an opportunity for a better work environment and productivity; employees have more flexible hours. This study mentions that home office employees have a lower disease rate, greater job satisfaction and higher performance in activities.

The problem cited by Oliveira (2017) in relation to the home office as a relationship between work and information technologies is not only focused on how work is organized, but also on organization and life; how the articulation of private life and work takes place in the context of the development of work activity in a new environment, the family.

The home/work interaction can become a worrying factor, as work is moved from the company to the family environment without the proper adaptation to the new environment, without the proper guidelines of advantages and disadvantages (Kurkland and Bailey, 1999). The home office has the advantages of removing people from the highways, the opportunity to be at home, favorable behavioral results, increased productivity and legal issues. On the other hand, it has as disadvantages the inability of managers to observe, on the spot, the employee's performance, which undermines the reliable and constructive performance feedback. 
The participants in the study by Rafalski et al (2015), pointed out that it is not enough to worry about installing a home office as an incentive for employees to accept work in a family environment, it aims to return attention to the characteristics of each individual, with caution in resistance to frustrations and ability to motivate oneself, due to the distancing of colleagues and the organization that can be minimized by policies of approximation on the part of companies and constant feedbacks.

Among the teleworkers' discourse/practice in the study by Costa (2007) transcends the discourse itself, as they envision entrepreneurship in itself, for being a project that directs their own lives, for not establishing the presence of the individual in a pre-established place. It is a project that transposes the organizational roles, or even the organization, in which people work. Despite the freedom of the project, the workers criticized the excess of working hours, transfer of costs, isolation, invasion of the family environment because it also became the work environment; and yet with two barriers: isolation and family, which may be possible resistances.

The home office enables a new experimentation for professional development, which is still a proposal of the new governance of contemporary organizations, which articulates entrepreneurship itself, brings a sense of well-being, self-sufficiency, the worker becomes responsible for your actions. This reality becomes the standard for teleworkers, being the new proposal for the new management of "domestic" work; however, returning to the office would be to relieve the space of the house, less hours worked and the rest of not thinking about work all the time.

\subsection{Covid-19 pandemic}

Pandemia is a word of Greek origin, formed with the neutral prefix pan and demos, people, mentioned by Plato for the first time in his book "The laws", which he used in a generic sense: any event capable of reaching the entire population, followed also by Aristotle's understanding; Galen related a pandemic to widespread epidemic diseases (Rezende, 1998).

The word pandemic was incorporated in the medical glossary from the 18th century onwards, which was conceptualized as an epidemic of great proportions, spreading in several countries and to more than one continent, as the Spanish flu in 1918, which caused the death of about 20 million people worldwide (Rezende, 1998).

The 1918-1919 flu - known as "Hespanhola Influenza" - according to Killingray (2009) was the most deadly to date; the flu virus is unstable and unpredictable and from time to time, undergoes mutations and takes on a more lethal form that resists antibodies acquired from the previous infection; the virus - H1N1 - was contagious and spread very quickly, reaching barracks, factories, public transport, ships and overcrowded buildings; it was a democratic virus, reaching rich and poor, urban and rural inhabitants (Delacy, 1993).

The 1918-1919 pandemic affected government activities, officials became ill and missed work; there were no people to carry out these activities, which is why many countries do not have a collection with data about the facts related to that time; much information is sought from non-governmental sources (Killingray, 2009).

In Brazil, due to the Public Administration's disregard for the 1918 Pandemic, the population mobilized to demand measures such as quarantine and isolation, and doctors recommended isolating patients (Goulart, 2005). At that time, the states of the federation had the autonomy to make the decisions they considered relevant, and some states closed schools such as Rio de Janeiro and Rio Grande do Sul. Although that pandemic had been considered as the "clean old" disease, the most affected were people in the working age between 20 and 40, who when leaving for work ended up infected (Alves, 2020).

In the Covid-19 pandemic (Corona Disease 2019), Covid-19's first official case was in a patient from Wuhan, China, on December 12, 2019; the World Health Organization (WHO) declared an international public health emergency in March 2020. After the entrance of Covid-19 in Brazil, several control and prevention measures were taken by health authorities from all spheres of the national territory. Among the measures, social distance was established, as it is a measure that is easily understood by the population (Bezerra, Silva, Soares and Silva, 2020).

Determinant for coping with the Covid-19 disease is to decrease the circulation of people on the streets and public collective spaces. Data from the research by Bezerra et al (2020) reveal that a considerable part of the population is contributing to this purpose, as they believe that the isolation strategy is effective to prevent the collapse in hospital care and the reduction in the number of victims of Covid-19, which lacks urgency for social protection measures and financial support for vulnerable social segments in times of crisis.

To deal with the possible consequences of the pandemic in Harvard Business School companies, by Gerdeman, presented a list of advice to guide the management of the home office - remote work in a pandemic time, when employees are not distracted by the commotion in their homes, as well as shaken by Covid-19 disease; managers must be aware of distractions in time of pandemic (Larson, Vroman and Makarius).

Classic remote work serves as an escape from breath for employees to share other activities, such as taking a walk, washing a load of dirty clothes, or starting dinner, while performing work activities (Gerdeman, 2020). The author mentions that there are cases in which the employee with small children at home, or someone caring 
for older relatives, or a worker needing to focus on their own physical and mental health as a result of the situation will certainly not be able to reach the weekly goal.

Clear and decisive communication for better concentration at work, presentation by managers clear priorities to be developed by employees, which present perspectives to employees, due to the fact that they cannot reassure about the future, the authors Gerdeman (2020) and Larson, Vroman and Makarius (2020) consider that the lack of face-to-face supervision is a cause for concern on the part of employees due to social interaction and in other cases they fear for reduced access in support and communication.

For the authors, in social isolation loneliness is common in remote jobs, due to the lack of this social interaction. The commitment expected by employees can create conflicts between these employees' personal and professional identities and affect performance (Gerdeman, 2020). Managers must not interfere with how the employee will manage his time to perform his activities as well as the way they will be performed; because there has been a radical change in their lives, results should be expected instead of monitoring activities.

For business leaders who were reluctant to adopt remote work have the opportunity to see its benefits, without the need for offices equipped with happy employees and increased productivity; this moment opened the door for a change and the adoption of the home office work culture (Gerdeman, 2020).

\section{Methodology}

Qualitative methodological procedures with exploratory characteristics were adopted. The organizations analyzed are public and private companies, whose choice was made through the snowball technique, considering the description of procedures by Vinuto (2014). The proposed approach is adequate to the objective of the study because it allows the approximation between the object and the researcher (Denzin and Lincoln, 2006).

Understanding the subjective aspects intrinsic to the subjective reality scape from quantifying analyzes (Mesquita and Matos, 2014), in addition to the whole apparatus of data collection techniques that include interviews, observations and documentary analysis (Patton, 2002). According to Flick (2004), the researcher in his considerations and reflections on field observations, impressions, notes, feelings, make part of the research data and part of the interpretation.

The contacts with public and private employees were made by the researchers, having as an essential characteristic the exercise of their activities in public and private companies.

Initially, an invitation was made to 36 people, including public and private employees, and it was sought that they were the same number for each company, however only 32 employees of the institutions accepted the invitation to participate in the research. The only requirement requested by the researchers was that the responses were sent via audio, however 4 respondents sent the responses in writing. For this reason, these responses were refuted for the analysis of the result and discussion. Data collection took place between May 16 and 25, 2020.

As a form of data collection, they were carried out through a questionnaire. The questions were sent by Whatsapp to the guests, who forwarded them via audio, in the same application, which were transcribed and sent back to the respondents to validate. The questionnaire consisted of a structured script with 18 questions, divided into two stages. In the first, there are questions about personal data: 1) State of the federation?; 2) Gender; 3 ) Age; 4) Income; 5) Education?.

The second stage, were questions about digital settlement: 6) In the first moment, what did you think of the Corona virus - Covid19?; 7) What was your reaction when you were informed that you should do your work activities at home office?; 8) Did the institution you work provide all the support for working in the home office? If so, which ones?; 9) Did you have a burden to settle in the home office?; 10) What is the biggest difficulty you identified as working at home office?; 11) Can you maintain the goal set by your institution? If negative, what factors make it difficult to reach the goal?; 12) How many people live with you?; 13) How are you dealing with family and work in the same environment?; 14) Do you have children who are with you at school? 15) Do you go through moments of anxiety? If so, what do you do to minimize this feeling?; 16) Did the institution you work for provide an access channel for psychological assistance in this pandemic moment? If so, which ones? Have you used it?; 17) In times without a pandemic, did you plan to work in the home office, if so, for what reasons?; 18) How do you imagine the face-to-face work will be when the distance restrictions decrease?

To the respondents were guaranteed the confidentiality and privacy of personal information. We inform them that any data that can identify them would be omitted in the disclosure of the research results and that the data will be stored in a safe place; that at any time, during the research, or later, they could request information about participation or about the research, so that their doubts would be clarified by the authors of this article.

In order to evaluate, test and define practicality of the methodology and clarity of understanding of the data collection instrument, the pre-test was carried out on May 13 and 14, 2020. Two questionnaires were applied: one with a public servant, and another with a private company employee, in order to check the consistency and integrity of the answers. This technique aims to reduce the chances of incomplete questionnaires when the instrument is designed and tested. Thus, it is possible to detect possible misleading questions and / or incomplete instructions before taking the main questionnaire. 
In order to understand the meanings of the text, discourse analysis conjectures that "a hidden meaning must be captured, which without an appropriate technique, remains inaccessible" (Maingueneau, 1989, p.11), in this understanding, we sought to work on the grouping of questionnaires in the same dialectic, allowing analysis of the ideas implied in the respondents' discourse; according to Siqueira (2003), "discourse analysis seeks to understand how a given symbolic object will bring about a meaning"; in the same conception Bardin (1977, p. 14) says that "behind the apparent discourse, usually symbolic and polysemic, there is a hidden meaning that should be unveiled"; while the categorization follows the guidelines of Bardin (1988).

\section{Results and Discussion}

Initially, data related to the criteria used as filters for the selection of respondents are presented, which were: state of the federation, sex, age and level of education and how much the institution's classification, whether public or private, has been previously identified by the researchers, which is why it is not in the questionnaire. Through these data, it was possible to analyze the profile of the group of respondents, validate the information and situate the results achieved from the working relationships in those existing in Brazil during the period of this research.

By analyzing the responses obtained, we sought to understand how public and private employees perceive work in the home office during the pandemic period.

The results are presented by classification of the surveyed companies, whether public or private, and consider two dimensions: in the first questioning the respondent's personal data, which brings a view of their profile; and the second about the digital settlement that allows us to understand how respondents perceive work in the home office during the pandemic period.

The analysis of the information collected in each of the companies was carried out and compared to the results found in each one of them. In order to facilitate the identification of the transcriptions of excerpts from the questionnaires carried out for the results analysis texts, an identification code was stipulated for each respondent. This code consists of five characters, with the first three identifying the company and the last two identifying the respondent.

\subsection{Respondent group analysis}

Questionnaires were carried out with twenty-eight individuals in the survey, distributed as follows:

Table 1

Distribution of the number of employees

\begin{tabular}{ccc}
\hline Type of collection instrument used & Public Company & Private Company \\
\hline Individual responses with employee & 14 & 14 \\
\hline Regarding the classification by state of the federation of respondent employees, they were distributed as \\
follows:
\end{tabular}

Table 2

Distribution by employee status

\begin{tabular}{ccc}
\hline States & Public Company & Private Company \\
\hline Distrito Federal & $2-14,3 \%$ & $3-21,4 \%$ \\
Rondônia & $12-85,7 \%$ & $5-35,7 \%$ \\
Goiás & $0-0,0 \%$ & $4-28,6 \%$ \\
São Paulo & $0-0,0 \%$ & $1-7,1 \%$ \\
Rio Grande do Sul & $0-0,0 \%$ & $1-7,1 \%$ \\
\hline
\end{tabular}

As for the segmentation by gender, the respondents were divided as follows:

Table 3

Distribution of employees by gender

\begin{tabular}{ccc}
\hline Genre & Public Company & Private Company \\
\hline Female & $7-50 \%$ & $9-64,3 \%$ \\
Male & $7-50 \%$ & $5-35,7 \%$ \\
\hline
\end{tabular}

According to the survey, the number of female and male people in the public company was the same: 7 female people and 7 male people, that is, $50 \%$ of each gender. While, in the private sector, the number of female individuals stood out with 9 participants, which corresponds to $64.3 \%$ of respondents and the male gender was 5 participants, corresponding to $35.7 \%$ of questionnaires. It is observed that among respondents in the private 
sphere, the number of people of the female gender is quite significant, which leads us to realize that the female gender is increasingly inserted in the labor market in the private sector. Table 4

Regarding the distribution by age, the following numbers are observed in the companies analyzed:

Distribution of age group employed

\begin{tabular}{ccc}
\hline Age range & Public Company & Private Company \\
\hline$<30$ anos & $1-7,1 \%$ & $2-14,3 \%$ \\
30 a 40 anos & $3-21,4 \%$ & $2-14,3 \%$ \\
40 a 50 anos & $5-35,7 \%$ & $6-42,1 \%$ \\
$>50$ anos & $5-35,7 \%$ & $4-28,6 \%$ \\
\hline
\end{tabular}

In a survey carried out in public and private companies, it was observed that the number of employees of those companies under the age of 30 in the population is $10.71 \%$, while the largest representation is between the age group of 40 to 50 years which makes up the percentage of $39.29 \%$ of the group of respondents in companies, followed by employees over 50 years of age, which is $32.14 \%$ of public and private employees and, finally, the respondent employees in the age group from 30 to 40 years represent $17.86 \%$ of the workforce. Note that the highest percentage is in the age group is between the age of 40 and over 50, which can be inferred that there is an aging workforce in the country.

Table 5

Distribution of schooling of employees

\begin{tabular}{ccc}
\hline Education & Public Company & Private Company \\
\hline Incomplete higher education & $1-7,1 \%$ & $3-21,4 \%$ \\
Complete higher education & $4-28,6 \%$ & $5-35,7 \%$ \\
Graduate & $7-50,0 \%$ & $3-21,4 \%$ \\
Master & $2-14,3 \%$ & $1-7,1 \%$ \\
Doctorate & $0-0,0 \%$ & $2-14,3 \%$ \\
\hline
\end{tabular}

It is observed that from the group of respondents all have already completed high school. The private company has the largest number of employees with incomplete superiors, with $10.71 \%$ of the entire population surveyed; however, it has a higher percentage of employees with postgraduate degrees at the doctorate level, with $14.3 \%$ of respondents, while the public company did not have any representative with such education. The largest representation of employees with higher education was from the private company, with $17.86 \%$ of the entire group of public and private respondents. As for education at the graduate level, the public company is represented by $25 \%$ of the employees of the total respondents in the survey. Finally, regarding the level of education in postgraduate studies at the master's level, the percentage of public and private companies is $7.14 \%$ and $3.57 \%$ respectively.

It is noted that there is a pretension in search of improvement by the employees of the two institutions, considering that in the question of the questionnaire survey, only the education level was requested. It is known that there is an increasing demand for improvement on the part of the employee, which cannot be said to have a substantial impact on their remuneration.

\subsection{Analysis of digital settlement data}

The purpose of the study was to present the analysis of the data collected when digitally settling in public and private companies (2020) in order to understand how public and private employees perceive work in the home office during the pandemic period.

Identifying the criteria, through a thorough reading of all the transcripts of the questionnaires, allowed the identification of important aspects pointed out in the reports of the questionnaires. It also made it possible to identify a hidden meaning (Maingueneau, 1989, p.11); to analyze ideas implied in the speech of the respondents Siqueira (2003), and to understand how a given symbolic object makes sense in the respondent's point of view, according to Bardin (1988) that should be unveiled. Thus, the criterion for identifying the theme: digital settlement is summarized in relation to the criteria adopted and the evidence found in the study, as shown in Chart 1: 
Chart 1

Analysis criteria for digital settlement

\begin{tabular}{|c|c|c|}
\hline Questions & Public Company & Private Company \\
\hline $\begin{array}{l}\text { At first moment what } \\
\text { did you think of } \\
\text { Coronavirus- Covid19? }\end{array}$ & $\begin{array}{l}\text { - I thought it was an exaggeration; } \\
\text { - I was following the situation; } \\
\text { - I didn't know the severity of the } \\
\text { disease. }\end{array}$ & $\begin{array}{l}\text { - I thought it was one more of a flu; } \\
\text { - People would lose their jobs and many } \\
\text { would die as a result of Covid-19; } \\
\text { - We were facing a worldwide change }\end{array}$ \\
\hline $\begin{array}{l}\text { What was your } \\
\text { reaction when you } \\
\text { were told that you } \\
\text { should do your job at } \\
\text { the home office }\end{array}$ & $\begin{array}{l}\text { - I was happy } \\
\text { - Although I was surprised I understood } \\
\text { that it was a measure I started to look } \\
\text { with good eyes; } \\
\text { - I was a little anxious, because I know } \\
\text { that I don't have so much discipline to } \\
\text { work at home. }\end{array}$ & $\begin{array}{l}\text { - Suppressed, but already imagined, because } \\
\text { I work in a private institution. } \\
\text { - Actually I was happy, it was a happy } \\
\text { moment, I would still have a job } \\
\text { - I was very ambivalent, part of me liked it } \\
\text { and another part did not, since I would need } \\
\text { to demand a specific structure for this. }\end{array}$ \\
\hline $\begin{array}{l}\text { Did the institution you } \\
\text { work provide all the } \\
\text { support for working in } \\
\text { the home office? If so, } \\
\text { which ones? }\end{array}$ & $\begin{array}{l}\text { - The institution did not provide } \\
\text { anything; } \\
\text { - Yes, all conditions were available; } \\
\text { - Regarding the entity I work with, the } \\
\text { entire structure for the home office was } \\
\text { made available. We have a different } \\
\text { reality, we don't work with electronic } \\
\text { process yet }\end{array}$ & $\begin{array}{l}\text { - Yes, it made some available, such as } \\
\text { Google Meet, Google Classroom, both } \\
\text { Google tools; } \\
\text { - No, I acquired everything myself; } \\
\text { - the accesses that we would have to do } \\
\text { from home, in the company's corporate } \\
\text { equipment }\end{array}$ \\
\hline $\begin{array}{l}\text { You had expenses to } \\
\text { settle in the home } \\
\text { office }\end{array}$ & $\begin{array}{l}\text { - I didn't have any extra charges to } \\
\text { install; } \\
\text { - No, I had no expenses to work; } \\
\text { - Yes, I started to consume more } \\
\text { electricity and started to share my work } \\
\text { time with other activities in the house }\end{array}$ & $\begin{array}{l}\text { - The expenses that I have to work at home } \\
\text { office is the payment of the internet; } \\
\text { - I didn't have a suitable table, nor } \\
\text { comfortable chairs in my house, I had to buy } \\
\text { a table and now I'm going to buy a chair; } \\
\text { - Yes, because I have to spend a lot more } \\
\text { time in front of the computer, this has } \\
\text { brought me health problems. }\end{array}$ \\
\hline $\begin{array}{l}\text { What is the biggest } \\
\text { difficulty you } \\
\text { identified with } \\
\text { working at home } \\
\text { office? }\end{array}$ & $\begin{array}{l}\text { - The biggest difficulty was because I } \\
\text { am a woman and a mother having to } \\
\text { take over the activities of the house and } \\
\text { the activities with the daughter; } \\
\text { - The biggest difficulty I felt was the } \\
\text { technique, the computer that was made } \\
\text { available is very old; } \\
\text { - Adequate location with adequate } \\
\text { structure and adequate silence. }\end{array}$ & $\begin{array}{l}\text { - The biggest difficulty is having the focus. } \\
\text { Working on the side of the bed is very } \\
\text { difficult, there are times when we disperse, } \\
\text { there are times when other people in the } \\
\text { house also make you disperse. } \\
\text { - The biggest difficulty was the schedules, } \\
\text { because the home office ended up exceeding } \\
\text { eight hours a day, and the job required more } \\
\text { time to be performed. } \\
\text { - My biggest difficulty was my access to my } \\
\text { service network }\end{array}$ \\
\hline $\begin{array}{l}\text { Can you maintain the } \\
\text { goal set by your } \\
\text { institution? If negative, } \\
\text { what factors make it } \\
\text { difficult to reach the } \\
\text { goal? }\end{array}$ & $\begin{array}{l}\text { - I managed to keep the goals, however } \\
\text { I started working much more hours } \\
\text { than if I had been making the electronic } \\
\text { punch clock; } \\
\text { - There are days that we produce more, } \\
\text { there are days that we produce less; } \\
\text { - Yes, I have managed to meet the } \\
\text { goals. }\end{array}$ & $\begin{array}{l}\text { - Yes, so far, we have been able to work } \\
\text { with what was proposed by the institution; } \\
\text { - I can maintain the goals established by the } \\
\text { institution; } \\
\text { - Yes, I'm doing it, and it's still possible to } \\
\text { maintain it. It is not being difficult. }\end{array}$ \\
\hline
\end{tabular}




\begin{tabular}{|c|c|c|}
\hline $\begin{array}{l}\text { How is it being to deal } \\
\text { with family and work } \\
\text { in the same } \\
\text { environment? }\end{array}$ & $\begin{array}{l}\text { - Working with the family in the same } \\
\text { environment is not cool, I have a lot of } \\
\text { annoyance, the children always make a } \\
\text { noise on their cell phones. It takes away } \\
\text { my concentration; } \\
\text { - We are adapting. Here, we did a } \\
\text { division of tasks at home; } \\
\text { - Dealing with family and work in the } \\
\text { same environment is not necessarily } \\
\text { complicated, in my case the biggest } \\
\text { difficulty is still the administration of } \\
\text { domestic tasks. }\end{array}$ & $\begin{array}{l}\text { - We try to adapt, everyone has to work, } \\
\text { there is a school, so everyone stays in their } \\
\text { corner and we try to adapt; } \\
\text { - It's very difficult, I, in particular, have to } \\
\text { wait for my son to sleep in order to record } \\
\text { my classes and produce material as well. So, } \\
\text { I spend three days a week without sleep, } \\
\text { producing material and recording; } \\
\text { - It's being (laughs). This question is } \\
\text { interesting, it's been very interesting, you } \\
\text { see; why, it is difficult to separate one thing } \\
\text { from the other; }\end{array}$ \\
\hline $\begin{array}{l}\text { Do you have moments } \\
\text { of anxiety? If so, what } \\
\text { do you do to minimize } \\
\text { this feeling? }\end{array}$ & $\begin{array}{l}\text { - I spent a few anxious moments just in } \\
\text { the beginning and then I was going to } \\
\text { make a coffee, I made several bottles of } \\
\text { coffee; } \\
\text { - Yes, I have moments of anxiety, } \\
\text { worry, fear, anguish, doubt, } \\
\text { uncertainty; I have been doing physical } \\
\text { activities on a regular basis; } \\
\text { - I do have moments of anxiety and } \\
\text { worry, they are not so frequent, but } \\
\text { there are some moments; listen to } \\
\text { music, try to distract and lie down and } \\
\text { try to get some sleep. }\end{array}$ & $\begin{array}{l}\text { - For sure, I go through moments of anxiety. } \\
\text { To minimize this feeling, I really like taking } \\
\text { care of the plant, also doing a good house } \\
\text { cleaning, exercising; } \\
\text { - No, I have no anxiety problem; } \\
\text { - I am naturally anxious, I am agitated, quite } \\
\text { agitated; and what reduced my anxiety are } \\
\text { two reasons: 1) the silence, that this in the } \\
\text { home office is great; } 2 \text { ) Yes, I can focus, so } \\
\text { if nobody is talking to me, focus on some } \\
\text { activity, it reduces my anxiety and } 3 \text { ) and } \\
\text { main, a lot of prayer, attending mass online, } \\
\text { praying a lot. }\end{array}$ \\
\hline $\begin{array}{l}\text { Has the institution you } \\
\text { work for provided } \\
\text { psychological } \\
\text { assistance in this } \\
\text { pandemic moment? If } \\
\text { so, which ones? Have } \\
\text { you used it? }\end{array}$ & $\begin{array}{l}\text { - Yes, it provided psychological } \\
\text { assistance; } \\
\text { - I am the help (laughs), so I already } \\
\text { did the service before, we already } \\
\text { provided assistance to employees, but } \\
\text { now we are serving everyone online; } \\
\text { - They will make it available, yet. They } \\
\text { made a program and opened the } \\
\text { registration for anyone who wanted to } \\
\text { work helping. }\end{array}$ & $\begin{array}{l}\text { - Yes, we have an assistant for mental health } \\
\text { issues; I didn't use it for myself, but I used it } \\
\text { for my team. } \\
\text { - The institution that I work offers a health } \\
\text { plan with psychological assistance, I did not } \\
\text { need to use it. } \\
\text { - Not available. }\end{array}$ \\
\hline $\begin{array}{l}\text { In times without a } \\
\text { pandemic, did you plan } \\
\text { to work in the home } \\
\text { office, if so, for what } \\
\text { reasons? }\end{array}$ & $\begin{array}{l}\text { - I didn't think for structural reasons } \\
\text { and for concentration, that the work } \\
\text { would be totally dedicated and focused } \\
\text { on the activity; } \\
\text { - I was never interested in working in } \\
\text { the home office, because I like the } \\
\text { interaction with colleagues, to discuss } \\
\text { legislation, to leave the domestic } \\
\text { environment; } \\
\text { - No, I like the routine of leaving home. } \\
\text { I don't like the idea of making my home } \\
\text { a place to work. }\end{array}$ & $\begin{array}{l}\text { - Yes, I already thought of working at home } \\
\text { office for financial reasons; } \\
\text { - Yes, when in times of pandemic, I agree to } \\
\text { work in the home office, because we already } \\
\text { have this experience inside the office; } \\
\text { - No, no, because I like this interaction of } \\
\text { the office, working with people, so it was } \\
\text { not an option I would like to do. }\end{array}$ \\
\hline
\end{tabular}


How do you imagine the face-to-face work will be when the distance restrictions decrease?

$$
\begin{aligned}
& \text { - I do not know how it will be, I believe } \\
& \text { it will take time to readapt again. Just } \\
& \text { as the home office was adapted, a new } \\
& \text { readaptation for face-to-face work will } \\
& \text { be necessary, as it is another system; } \\
& \text { - This is a question I have been asking } \\
& \text { myself frequently: what will our new } \\
& \text { moment be like in the post pandemic? } \\
& \text { But I have no idea, I don't believe it } \\
& \text { will ever return to normal; } \\
& \text {-I think a lot will change; I believe that } \\
& \text { we will maintain this service online; } \\
& \text { - I think the pandemic is showing that } \\
& \text { many of the activities that we carry out } \\
& \text { today, really, do not depend on physical } \\
& \text { presence. }
\end{aligned}
$$

- When the distance restrictions decrease and I can go back to work in person, I think it will be a very bad time, because I really like working in the home office, I even prefer it and I hope that the company I work for gives me this opportunity to continue; - Well, on the one hand it opens the door to work and, one day or another in the home office, which makes it easier for those who have a family away, who need to travel. This happens a lot here in the company, on the other hand, I think people will be more hygienic;

- I haven't thought about the future yet, to be honest I haven't really imagined what it will be like after going through this crisis.

Based on the evidence pointed out, the analysis of the criterion associated with the dimension of the study was performed. In sequence, the analysis for each company and the comparative study between them are presented.

\subsubsection{Analysis of the Public Company}

At the Public Company, fourteen employees responded, of which only one is a manager, who, because of his activity, was briefly in the home office; because, due to the non-electronic processes, he took home, at the risk of spreading the disease, Covid-19, to the family environment.

The first criterion considered was "what did you think of Coronavirus-Covid19?", The question was inserted by the fact that the disease was the factor that led to the imposition of the home office on employees. From the responses that were obtained from public employees, it was observed that all respondents were already aware of the disease that caused the pandemic. It is noted in the response of the employee PUB11 "I thought that the Coronavirus would not leave China". Although aware of the disease, the respondent was unaware of the disease's ability to spread, either because of other diseases of origin in that country, they were limited to that region, or even not worrying about what could happen if they arrived in Brazil. The PUB14 employee followed the same understanding, who said: "I confess that I didn't give it much importance, I didn't believe it would become a pandemic". In that speech, the respondent later noted the seriousness of the situation that affected the country. It can be linked to the speech of the respondents, the point of view of Goulart (2005), when he says: while in Europe the Spanish flu hit the people, in Rio de Janeiro, "the news about the reigning evil was ignored or neglected and in a humorous tone, even in a tone of pseudo-scientificity, illustrating a strange feeling of immunity in the face of the disease".

Respondents were asked to know: "what was your reaction when you were informed that you should do your work activities in the home office?". The responses varied from euphoria, as said by respondent PUB02 "when I heard about the adoption of the home office in my work I was very happy". This feeling of happiness may implicitly be linked to family protection or also to the refuge from socio-environmental problems at work, which imprisons the employee, and the possibility of home office frees him from the pseudo prison.

On the other hand, the employee PUB10 reports that: "I was a little anxious, because I know I don't have so much discipline to work at home, I like this routine of going to work, [...].”. For Rafalski et al. (2015) the act of being in a home office needs adaptation to the new work environment, in addition to family and employee consent; managers must communicate regularly with their employees, not only for work reasons, but also for psychological issues arising from the stress caused by managing the limits of work and the family environment (Grant, Wallace and Spurgeon, 2013). Although the reaction of the employees is different, in times of pandemic, the employee's feelings are not immediately rated by the company, because at that moment what is sought is the safety and preservation of the employee's life.

In the question "how do you imagine the face-to-face work will be when the distance restrictions decrease?". The intention to imagine the future in a pandemic season is not inspiring due to the number of deaths in the country, the responses were favorable to working in the home office, as seen in the statement by respondent PUB04 "I think the pandemic is showing that many activities that we carry out today, do not really depend on physical presence, [...].". This discourse already reflects a change in the profile of some activities in public administration, according to Publix (2019) in Brazil, the best known case of home office was at the Federal Court of Accounts (TCU), which implemented this type of service in 2009, followed by the Superior Labor Court (TST), which started remote work in 2012. Virtual work is already a broad trend in the labor market, which is why the number of people involved in the home office is becoming more and more important and 
visible (Holts, 2018).

In the same sense, the respondent PUB09 says that: "in relation to the return of face-to-face work, I see that it will return to be more or less normal, but I believe that with the establishment of teleworking services, home office and with habit, I believe that this is increasingly a new reality for the civil servant; [...] ", with the practice already being sponsored by some public institutions, with the experience in times of pandemic will change the scenario of public companies, as mentioned by the respondent PUB02" [...], the return to my view it means a setback, because teleworking is an economy for public coffers, if you imagine how much you save energy, water, cleaning products, maintenance products, it is incalculable; and since the server can work and produce more at home, combined with the economy that gives to the coffers, it would be a setback, [...]".

4.2.2 Analysis of the Private Company

Respondents from private companies were also fourteen employees, one of whom holds a managerial position and considered that the institution made psychological support available during a pandemic time, and was used through a meeting of the group of employees.

As for the criterion "The institution you work for has made all the support available for work in the home office? If so, which ones?". The intention of the questioning was to know the positioning of the company in a troubled period regarding the availability of tools for the employee to carry out his activities, the respondent PRI02 said "yes, he made available some, such as Google Meet, Google Classroom, both, Google tools", according to the respondent, is that he had to maintain the burden with the work tools.

While the respondent PRI04 says: "no, I acquired everything myself", he paid the entire burden to equip himself to develop his work activities; the term alone implies that he was abandoned by the company, when he was forced to carry out his activities in the home office. Rafalski et al. (2015) says that in order to ponder the negative aspects of family-work and work-family conflicts, it is necessary that companies invest both in the personal and professional sphere of employees for the interaction of the terms work/family/work.

Another question that sought to be answered in the questions was "What is the biggest difficulty you identified with working in the home office?". The question sought to identify both operational and environmental difficulties, and the following response was obtained from respondent PRI02: "the greatest difficulty is to hold the students' attention and try not to leave classes so monotonous due to the possibilities of methodology being smaller on the platform of the than in the classroom ". The employee's concern is that teaching is already difficult in the classroom environment, perhaps in the virtual environment, which in times of pandemic is a constant complaint from parents and students for being a new tool for many and for others inaccessible .

In turn, the respondent PRI11 mentioned that: "The number of tasks that I need to require from students has increased, as well as my health, which has become complicated. I have a problem with the cervical vertebra and the problem has increased. I've been feeling a lot of headaches, back pain, anyway ". From this respondent's statement, it is observed that in addition to a pre-existing chronic problem, the occurrence of others. Boredom is perceived in an implicit way, which can be confirmed with the answer to the question "How do you imagine the face-to-face work will be when the distance restrictions decrease?". The respondent just said: "I think it will go back to how it was before."

Another criterion of the survey was "in times when there was no pandemic, did you plan to work in the home office? If so, for what reasons?. The answer to this question, from respondent PRI01, says: "no, no! Because I like this interaction in the office, working with people. So it was not an option I would like to make"; in this speech it can be inferred that the respondent makes it clear that the house has one objective and the work has another, that is, they are different worlds. According to Kowalski and Swanson (2005) although there is resistance and challenges associated with working in the home office, many companies are successful in choosing this type of work activity, what is necessary is to implement effective programs that can be done through the technique of benchmarking

.In another sense, respondent PRI14 says "I had never thought of working in a home office before, but after that experience; so for my type of work, I think it is viable "; the term used by the respondent "I think it is viable" is noted that the experience in home office is healthy, which confirms with the respondent's answer in the question "Do you go through moments of anxiety? If so, what do you do to minimize this feeling?" . Her answer was: "I certainly go through moments of anxiety, to minimize this feeling, I really like taking care of plants, I also like to do a good house cleaning, [...]"; activities that are mainly done in a family environment.

4.2.3 Comparative summary between the responses of employees of Public and Private Companies

As for the analysis criteria related to the digital settlement of public and private companies, they had similar and some divergent aspects.

As for the first criterion that questions what was thought of Covid-19, the significant volume of respondents understood that the disease would not have the dimension it reached and would not even reach Brazil. Regarding the fact that they carry out activities in the home office, the answers were in two poles, positive and negative in both types of companies; and in the responses that said they liked the experience, they also reported their interest 
in continuing to work in the home office.

Regarding the installation of employees in their family environments, the answers were that: there was no charge, there was a charge to purchase parts of equipment to install in the home office and others had a burden to acquire everything to get equipped for work. The fact that it is burdensome can lead the employee to the negative thinking of the home office, without considering that he will be in a more protected environment and with his family.

The difficulties identified by workers in private companies were in terms of setting up with the family, health, operations and others said they had not identified any problems in the home office. Many of the problems identified in the questionnaires were due to the fact that the installation came without a physical planning related to the environment and financial for those who had and are burdened to stay in the home office.

Achieving the goal was not an obstacle for company respondents, with the exception of one respondent who said he found it difficult to deliver the targets on time. As for dealing with family and work, for many it is challenging, while for others it is satisfying to be together with the family exercising their activities.

Anxiety was mentioned by public and private employees, some of whom have already sought help from qualified professionals to deal with the matter, others are waiting for the institution to provide an access channel to be served and others have said that they have not passed and do not experience moments of anxiety. It is possible to notice that some companies already have a help channel for the pandemic moment.

The work in the home office was a surprise for some public and private employees, others understood the need to impose work in the home office; others are waiting for the return in face-to-face activity, however there were those who liked it and demonstrated to remain in the home office by employees at both companies.

As for the return to face-to-face work, both employees of public companies and private companies claimed that there will be changes in hygiene issues in the work environment; others realized that there will be behavioral change as well as the institution itself will undergo change, due to the fact that many employees already wanted to work in the home office, as for those who had a positive experience in this type of work and, finally, some hope not to change nothing and return to the status quo.

\section{Conclusion}

Finally, the pandemic endorses a new chapter for companies to deal with the new demand for work in the home office on the part of new supporters and those who already intended to exercise their work activities in an environment of their choice. In this case, it is not just the validation of work in the home office, there is a need to adapt the employee regarding psychosocial factors, as the requirement for productivity on a large scale and over time, there may be an overload bringing on occupational diseases in the environment that previously it would be your rest.

The study is important for public and private companies because it showed a new dimension to be developed by the Human Resources department and the Information Technology of companies, due to a possible demand for work in the post-pandemic home office. Also important was the weighting made by employees regarding the structural and behavioral demands that should be addressed by companies, if they adopt the home office.

Among the limitations found in the development of work was the non-selectivity of the class of public and private workers who, in a certain way, may have compromised the analysis, and in the case of private employees due to the activities performed by the employees involved in the research. In view of the limitations, further research is suggested in order to expand studies to carry out activities in the home office by public and private employees, with better separation of group of activities, to confirm the conclusion of this article.

\section{Reference}

Alves, Gabrielle Werenicz. (2020). Uma comparação entre a pandemia de Gripe Espanhola e a pandemia de Coronavírus. Available in: https://www.ufrgs.br/coronavirus/base/uma-comparacao-entre-a-pandemia-degripe-espanhola-e-a-pandemia-de-coronavirus/. Access in: 21.05.2020.

Bardin, L. Análise de conteúdo. Lisboa: Edições 70, 1977.

Bardin, L. Análise de conteúdo. Lisboa: Edições 70, 1988.

Bezerra, A., SILVA, Carlos Eduardo Menezes da., \& SOARES, Fernando Ramalho Gameleira, SILVA, José Alexandre Menezes da. (2020, Abr). Fatores associados ao comportamento da população durante o isolamento social na pandemia de COVID-19. Ciência Saúde Colet. Available in: http://www.cienciaesaudecoletiva.com.br/artigos/fatores-associados-ao-comportamento-da-populacaodurante-o-isolamento-social-na-pandemia-de-covid19/17551?id=17551. Access in: 15.05.2020.

Delacy, Margaret. (1993). The conceptualization of influenza in eighteenth-century Britain: specificity and contagion. Bull Hist Med. 67(1):75-117. Available in: http://www.contagionism.org/influenza_conceptualization.pdf. Access in: 29.05.2020

Denzin, N. K., \& LINCOLN, Y. S. (2006). O planejamento da pesquisa qualitativa: teorias e abordagens. 2 ed. 
Porto Alegre: Artmed.

Flick, U. (2004). Uma Introdução à Pesquisa Qualitativa; 2a , ed. Bookman, Porto Alegre/RS.

Gerdeman, Dina. (2020) As novas regras para o trabalho remoto: Edição Pandêmica. Março de 2020. Available in: https://hbswk.hbs.edu/item/the-new-rules-for-remote-work-pandemic-edition. Access in: 15.05.2020.

Goulart, Adriana da Costa. (2005, Jan/Apr). Revisitando a espanhola: a gripe pandêmica de 1918 no Rio de Janeiro. Hist. cienc. Saúde-Manguinhos vol. 12 n. 1. Rio de Janeiro.

Grant, C., Wallace, L.M., \& Spurgeon, P.C. (2013). An exploration of the psychological factors affecting remote e-worker's job effectiveness, well-being and work-life balance. Employee Relations, volume 35 (5): 527 546.

Hill, E, Jeffrey, Ferris Maria, \& Märtinson Vjollca. (2003). Does it matter where you work? A comparison of how three work venues (tradicional office, virtual office, and home office) influence aspects of work nad personl/Family life. Journal of Vocational Behavior 63, 220-241.

Holts, Kaire. (2017). Understanding Virtual Work: Prospects for Estonia in the Digital Economy. Available in: https://www.riigikogu.ee/wpcms/wp-content/uploads/2017/09/Virtual-work-size-and-trends_final1.pdf. Access in: 29.05.2020.

Killingray, David. 2009. 'A pandemia de gripe de 1918-1919: causas, evolução e consequências'. In: Jose Manuel Sobral, ed. A Pandemia Esquecida: Olhares comparados sobre a pneumónica 1918-19 (Forgotten Pandemic: Comparative views on the Spanish 'Influenza: 1918-19). Lisboa: Imprensa de Ciências Sociais, pp. 41-61.

Kowalski, K. Berube, \& Swanson Jennifer. Critical Success factors in developing teleworking programs. Benchmarking: An International Journal, Vol. 12 No. 3, pp. 236-249. https://doi.org/10.1108/14635770510600357.

Kurkland, N. B., \& Bailey, D. E. The advantages and challenges of working here, there anywhere, and anytime. Organizational Dynamics, 28 (2), 53-68 1999. doi: 10.1016/s0090-2616(00)80016-9. Access in: 18.05.2020.

Larson, Barbara Z.; VROMAN, Susan R. \& MAKARIUS Erin E. (2020). Como gerenciar funcionários que acabaram de mudar para um regime remoto. Gestão de equipes. Available in: https://hbrbr.uol.com.br/umguia-para-gerenciar-funcionarios-que-acabaram-de-mudar-para-um-regime-remoto/. Access in: 20.05. 2020.

Mesquita, R. F. \& MATOS, F. R. N. (2014). Pesquisa qualitativa e estudos organizacionais: história, abordagens e perspectivas futuras. In: COLÓQUIO INTERNACIONAL DE EPISTEMOLOGIA E SOCIOLOGIA DA CIÊNCIA DA ADMINISTRAÇÃO, 4. Anais. Florianópolis.

Nippert-Eng, Christea. Calendars and Keys: The Classification of "Home" and "Work". (1996). Sociological Forum, Vol. 11, b. 3.

Oliveira, Daniela Ribeiro de. (2017). Do fim do trabalho ao trabalho sem fim: o trabalho e a vida dos trabalhadores digitais em Home Offce. Repositório Universidade Federal de São Carlos.

Organização Mundial da Saúde (OMS). Coronavirus (COVID-19). Available in: https://www.who.int/es/. Access in: 18.05.2020.

Patton, M. Q. Qualitative research and evaluation methods. (2002). London: Sage Publications.

Instituto PUBLIX. Teletrabalho no Serviço Público. Available in: https://institutopublix.com.br/teletrabalho-noservico-publico/. Access in: 29.05.2020.

Rafalski, Julia Carolina, \& De Andrade, Alexsandro Luiz. (2015, jun.). Escritório em casa: aspectos exploratórios do trabalho em casa. Períodicos Eletrônicos em Psicológia. Temas psicol.. vol. 23 n. 2, Riberão Preto. doi: 10.9788/TP2015.2-14.

Rezende, Joffre Marcondes de. (1998, jan-jun). Epidemia, Endemia, Pandemia, Epidemiologia. Revista de Patologia Tropical. Vol. 27(I): 153-155.

Siqueira, M. V. S. O imaginário organizacional moderno e o discurso do superexecutivo de sucesso na mídia especializada em negócios. 2003). FGV-EAESP, Iberoamerican Academy of Management International Conference, São Paulo.

Vinuto, Juliana. (2014). A amostragem em bola de neve na pesquisa qualitativa: um debate em aberto. Temáticas, Campinas, v. 22, n. 44, p. 203-220. 